\title{
Air pollution and non-respiratory health hazards for children
}

Roya Kelishadi', Parinaz Poursafa²

1Isfahan Cardiovascular Research Centre, Isfahan University of Medical Sciences, Isfahan, Iran

${ }^{2}$ Science and Research University, Tehran, Iran

Submitted: 12 June 2009

Accepted: 7 August 2009

Arch Med Sci 2010; 6, 4: 483-495

DOI: $10.5114 /$ aoms.2010.14458

Copyright ( 2010 Termedia \& Banach
Corresponding author: Prof. Roya Kelishadi, MD Isfahan University of Medical Sciences PO Box 81465-1148 Isfahan, Iran Phone: +98 $3113377881-8$ Fax: +98 3113373435 E-mail: kroya@aap.net, Kelishadi@med.mui.ac.ir

\begin{abstract}
Air pollution is a global health issue with serious public health implications, particularly for children. Usually respiratory effects of air pollutants are considered, but this review highlights the importance of non-respiratory health hazards. In addition to short-term effects, exposure to criteria air pollutants from early life might be associated with low birth weight, increase in oxidative stress and endothelial dysfunction, which in turn might have long-term effects on chronic non-communicable diseases. In view of the emerging epidemic of chronic disease in low- and middle- income countries, the vicious cycle of rapid urbanization and increasing levels of air pollution, public health and regulatory policies for air quality protection should be integrated into the main priorities of the primary health care system and into the educational curriculum of health professionals.
\end{abstract}

Key words: air pollution, children, health, prevention, chronic disease, public health.

\section{Introduction}

Air pollution is a mixture of solid particles and gases in the air. The six common and harmful air pollutants are particulate matter, ground-level ozone, carbon monoxide, sulfur oxides, nitrogen oxides, and lead; of these, particle pollution and ground-level ozone are the most widespread health threats [1, 2]. Because of their importance, a brief summary about these common pollutants, also known as criteria air pollutants, is provided here: particulate matter or PM consists of a heterogeneous mixture of very small particles and liquid droplets suspended in air. The size of particles in PM is directly linked to their potential to cause health problems. Particles with diameter $\leq 10 \mu \mathrm{m}$ are the particles that generally pass through the throat and nose and enter the lungs. Then, they can affect various body organs, especially the heart and lungs, and may cause serious health effects. Based on particle size, particle pollution is grouped into: a) "inhalable coarse particles" which have a diameter of $2.5 \mu \mathrm{m}$ to $10 \mu \mathrm{m}$, and are found near roadways and industries, and b) "fine particles" $<2.5 \mu \mathrm{m}$ in diameter such as those found in smoke and haze; they can form when gases emitted from power plants, industries and automobiles react in the air. Ozone $\left(\mathrm{O}_{3}\right)$ is a gas composed of three oxygen atoms. In the presence of sunlight, it is created at ground level by a chemical reaction between oxides of nitrogen and volatile organic compounds. Ozone might have harmful effects when formed in the earth's lower atmosphere, i.e. at ground level. 
Hot weather and sunlight cause ground-level ozone to form in harmful concentrations in the air. Carbon monoxide (CO) is an odourless, colourless gas formed by incomplete carbon combustion. It is mainly emitted from motor vehicle exhaust, followed by non-road engines such as construction equipment, industrial processes and wood burning. The increasing number of cars has an important role in the increase in $\mathrm{CO}$ emission worldwide. Sulfur dioxide $\left(\mathrm{SO}_{2}\right)$ is a gas formed when fuel containing sulfur, such as coal and oil, is burned, and when gasoline is extracted from oil or metals are extracted from ore. Nitrogen oxides $\left(\mathrm{NO}_{\mathrm{x}}\right)$ are a group of highly reactive gases containing various levels of nitrogen and oxygen. Lead is usually emitted from motor vehicles and industrial sources $[2,3]$. Other stationary sources are waste incinerators, utilities, and lead-acid battery manufacturers. In addition to exposure to lead in air, other major exposure pathways include ingestion of lead in drinking water and lead-contaminated food as well as incidental ingestion of lead-contaminated soil and dust. Lead-based paint remains a major exposure pathway in older homes. Some toys might contain considerable amounts of lead that would be harmful for children's health [1, 4].

Two types of air quality standards are considered: primary standards set limits to protect public health, including the health of "sensitive" populations such as asthmatics, children, and the elderly. Secondary standards set limits to protect public welfare, including protection against decreased visibility, damage to animals, crops, vegetation, and buildings. Numerous scientific studies have linked particle pollution exposure to a variety of health problems, including: increased respiratory symptoms, such as irritation of the airways, cough, difficult breathing, decreased lung function, trigger of asthma, chronic bronchitis, arrhythmias, heart attacks, premature death in people with cardiovascular or respiratory diseases, cough, dyspnoea, wheezing and chronic lung diseases. Carbon monoxide reduces oxygen delivery to the body's organs, and cardiovascular patients might experience its most serious effects. In addition, it may cause vision problems, reduced ability to work or learn and difficulty in performing complex tasks. At extremely high levels, $\mathrm{CO}$ is poisonous and can cause death. In addition, CO contributes to the formation of smog and its consequent respiratory problems. Sulfur dioxide can cause breathing difficulty for asthmatic patients. Longer-term exposure to high levels of Sulfur dioxide gas and particles may be carcinogenic and may cause respiratory disorders and aggravate cardiovascular diseases; it may also cause eye burning and headache. Sulfur dioxide and nitrogen oxides react with other substances in the air to form acids, which fall to earth as rain, fog, snow, or dry particles. Nitric dioxide $\left(\mathrm{NO}_{2}\right)$ can cause lung irritation, viral infection, airway resistance and chest tightness [3, 4].

Lead is distributed throughout the body in the blood and is accumulated in the bones. The most common effects of lead exposure are neurological effects in children and cardiovascular effects in adults. Infants and young children are especially sensitive to even low levels of lead, which may contribute to behavioural problems, learning deficits and lowered intelligence quotient (IQ). Infants and children are among the most susceptible age groups for air pollutants, because children may have greater exposure than adults to air pollutants. Infants and children have higher respiratory rates than adults, which would increase their exposure to air pollutants. Mouth breathing is more prevalent in infants and children than in adults; hence they bypass the filtering effect of the nose, and consequently they would inhale higher levels of pollutants than adults. Children generally spend significantly more time outdoors than adults, especially during summer time when smog levels are the highest. In addition, children's immune systems and developing organs are still immature [5].

Air pollution might have various adverse effects on children's health; some of the most important effects include perinatal effects, infant mortality, respiratory disorders, allergy, malignancies, cardiovascular disorders, increase in oxidative stress, endothelial dysfunction, mental disorders and vitamin D deficiency [6]. However, so far several studies and most information given to health professionals as well as to communities have focused on short-term respiratory effects of air pollution on children's health. In this review, we provide a summary of studies conducted on nonrespiratory effects of air pollution on children's health to draw more attention to the wide range of hazards of air pollution from early life, and their possible implications for chronic non-communicable diseases of adulthood.

\section{Search strategy}

Electronic databases used for a search of the literature to find relevant studies were as follows: 1) Ovid MEDLINE(R) (1978 to 2008 with weekly update),

2) Ovid MEDLINE(R) in process and other nonindexed citations (2008),

3) AMED (Allied and Complementary Medicine) (1988 to 2008),

4) CINAHL (Cumulative Index to Nursing and Allied Health Literature) (1988 to 2008),

5) EMBASE (1980 to 2008),

6) CAB Abstracts (1978 to 2008),

7) Global Health (1978 to 2008). 
The following search terms were used: air pollution, air pollutants, infants, children, adolescents, and youths. In a secondary search, we used terms related to health problems including abnormal development (low birth weight, preterm birth, prematurity, intrauterine growth restriction, congenital defects, intrauterine and infant mortality, malignancy, cancer, development, behavioural problems, neurocognitive decrements, etc).

Data on study design and location, air pollutants, confounding factors, health outcomes measured, and study results were extracted from the selected studies. Relevant articles cited by selected publications were also included.

\section{Search results}

Studies varied by design, study location, age group of study subjects, study duration and type of health outcomes studied. Some studies were crosssectional, some had a case-control design, and the most relevant studies used time-series analysis to investigate associations between daily variations in air pollutants and variations in health outcomes.

The most prominent health hazards are summarized in Tables I-V.

\section{Discussion}

The findings of this review underscore the importance of paying more attention to different aspects of hazards of air pollution on children's health, and not only to the direct effects on the respiratory system. Of special concern are the late-onset effects of air pollution in early life that may contribute to many chronic diseases later in life. Chronic non-communicable diseases are rapidly escalating in low- and middle-income countries [7], and their risk factors have a considerably high prevalence in different age groups even in children and adolescents [8-11]. The association of dietary and physical activity habits and these risk factors has been documented [12-15]; however, studies about the relationship of environmental factors, notably air pollution, with risk factors of chronic diseases are scarce in the paediatric age group.

Many studies have documented the effects of criteria air pollutants on low birth weight and or prematurity. The association of intrauterine growth retardation and low birth weight with increased risk of chronic non-communicable diseases such as obesity, hypertension and cardiovascular disease later in life is well documented [16]. In addition, prematurity can be associated with higher risk of such disorders [17]. Until now, most studies have linked maternal malnutrition to low birth weight of their children [18], and its implications for the risk of adult chronic diseases in low-income and middleincome countries have been documented [19].
Furthermore, low socio-economic position in early life is known as a predisposing factor for chronic diseases [20] and mortality [21] in adulthood. Usually improper lifestyle habits and low educational levels have been considered as the underlying process of such associations. We suggest that exposure to air pollutants and its effects on low birth weight and premature birth should be considered as well.

According to World Bank data, "urbanization is progressing much faster in developing countries than in developed countries, and most of the world's most populous cities are in developing countries. Many of these cities are in Asian countries with low per capita incomes but big populations. These cities have high concentrations of poor residents and suffer from social and environmental problems including severe air pollution" [22].

Similarly, the low-income and middle-income countries are facing an emerging epidemic of chronic non-communicable diseases in the near future [7, 23]. Lifestyle modifications as well as strengthening primary care in the health system have been considered as the main strategies to tackle chronic diseases in low- and middle-income countries [24].

We suggest that environmental protection actions, notably for reducing the emission of criteria air pollutants, should be considered for public health measures taken into account for primordial/primary prevention of chronic diseases, especially in developing countries.

The association between air pollution and chronic diseases may be mediated through systemic inflammatory responses [3, 25]. Generation of reactive oxygen species is linked to a variety of environmental factors. The association of air pollution and inflammation/oxidative stress has been demonstrated [26-28], even among healthy children [29] who might have the early stages of atherosclerosis.

The effects of air pollution on oxidative stress and endothelial dysfunction from early life confirm the necessity of implications of these findings in relation to public health and regulatory policies for prevention and control of adult chronic diseases from childhood.

Similar to cardiovascular diseases, the prevalence of malignancies is rapidly escalating worldwide. Although lifestyle behaviours such as smoking [30], as well as unhealthy dietary and physical activity habits leading to obesity and diabetes, are known as a major contributing factor in this regard [31], air pollution should be considered as another potential risk factor for developing countries [32], especially Asian countries where cancer has become an emerging health threat [33]. This issue is 
Table I. Summary of studies assessing the perinatal effects of criteria air pollutants

\begin{tabular}{|c|c|c|c|c|}
\hline $\begin{array}{l}\text { Reference } \\
\text { (1) }\end{array}$ & $\begin{array}{l}\text { Location } \\
\text { (2) }\end{array}$ & $\begin{array}{l}\text { Population studied } \\
\text { (3) }\end{array}$ & $\begin{array}{l}\text { Aims } \\
\text { (4) }\end{array}$ & $\begin{array}{l}\text { Findings } \\
\text { (5) }\end{array}$ \\
\hline $\begin{array}{l}\text { Zeka et al., } \\
2008 \text { [34] }\end{array}$ & $\begin{array}{l}\text { Eastern } \\
\text { Massachusetts, USA }\end{array}$ & All singleton births & $\begin{array}{l}\text { To examine the association between indicators } \\
\text { of traffic, land use, individual and area-based } \\
\text { socioeconomic measures, and birth outcomes }\end{array}$ & $\begin{array}{l}\text { Greater risk of reduced birth weight associated with } \\
\text { traffic exposures }\end{array}$ \\
\hline $\begin{array}{l}\text { Suh et al., } \\
2008[35]\end{array}$ & Seoul, Korea & $\begin{array}{l}\text { Birth data obtained from } \\
\text { the National Statistical Office } \\
(n=374,167)(1998-2000)\end{array}$ & $\begin{array}{l}\text { To determine whether the preterm risks due to PM10 } \\
\text { exposure vary with the exposure periods during } \\
\text { pregnancy }\end{array}$ & $\begin{array}{l}\text { Effect of PM10 exposure prior to the } 37 \text { weeks of the } \\
\text { gestational period on the risk of premature birth was } \\
\text { stronger than after that. The hazard ratios for preterm } \\
\text { delivery associated with PM10 exposure in the first } \\
\text { and third trimester were slightly higher than those } \\
\text { of the second trimester }\end{array}$ \\
\hline $\begin{array}{l}\text { Parker et al., } \\
2008[36]\end{array}$ & Utah, USA & All pregnant mothers in Utah & $\begin{array}{l}\text { To compare birth outcomes for Utah mothers within } \\
\text { and outside the Utah Valley, before, during, and after } \\
\text { the steel mill closure }\end{array}$ & $\begin{array}{l}\text { Mothers who were pregnant around the time of the } \\
\text { closure of the mill were less likely to deliver } \\
\text { prematurely than mothers who were pregnant before } \\
\text { or after; effects were strongest for exposure during } \\
\text { the second trimester }\end{array}$ \\
\hline $\begin{array}{l}\text { Stillerman et al., } \\
2008 \text { [37] }\end{array}$ & Review & PubMed search (1995-2006) & $\begin{array}{l}\text { To better understand the science linking } \\
\text { environmental contaminant exposures with adverse } \\
\text { pregnancy outcomes }\end{array}$ & $\begin{array}{l}\text { Environmental tobacco smoke is a risk factor for } \\
\text { reduced birth weight and preterm delivery. Outdoor air } \\
\text { pollution is associated with reduced term birth weight } \\
\text { and preterm delivery }\end{array}$ \\
\hline $\begin{array}{l}\text { Choi et al., } \\
2008[38]\end{array}$ & New York, USA & $\begin{array}{l}\text { Mother-newborn pairs } \\
(n=616) \\
\text { African-American }(n=224) \\
\text { and Dominican }(n=392)\end{array}$ & $\begin{array}{l}\text { To determine the effect of prenatal exposure to air } \\
\text { pollution on increasing the risk of low birth weight } \\
\text { and preterm delivery }\end{array}$ & $\begin{array}{l}\text { Prenatal exposure to polycyclic aromatic hydrocarbons } \\
\text { is likely to contribute to the occurrence of low birth } \\
\text { weight and preterm births among African Americans, } \\
\text { but not in Dominicans; this might reflect healthier } \\
\text { cultural practices among recent Dominican immigrants }\end{array}$ \\
\hline $\begin{array}{l}\text { Brauer et al., } \\
2008 \text { [39] }\end{array}$ & $\begin{array}{l}\text { Vancouver, British } \\
\text { Columbia, Canada }\end{array}$ & $\begin{array}{l}70,249 \text { singleton births } \\
(1999-2002)\end{array}$ & $\begin{array}{l}\text { To evaluate the impacts of air pollution on low birth } \\
\text { weight and preterm delivery }\end{array}$ & $\begin{array}{l}\text { Exposure to all air pollutants except } \mathrm{O}_{3} \text { was } \\
\text { associated with low birth weight. For preterm births, } \\
\text { associations were observed with PM2.5 for births } \\
<37 \text { weeks gestation, and for other pollutants } \\
\text { at }<30 \text { weeks }\end{array}$ \\
\hline
\end{tabular}


Table I. Summary of studies assessing the perinatal effects of criteria air pollutants - cont.

\begin{tabular}{|c|c|c|c|c|}
\hline (1) & (2) & (3) & (4) & (5) \\
\hline $\begin{array}{l}\text { Bell et al., } \\
2007[40]\end{array}$ & $\begin{array}{l}\text { Massachusetts and } \\
\text { Connecticut, USA }\end{array}$ & $\begin{array}{l}358,504 \text { births in } \\
\text { Massachusetts and } \\
\text { Connecticut (1999-2002) }\end{array}$ & $\begin{array}{l}\text { To investigate maternal exposure to particulate } \\
\text { matter with different air pollutants and birth weight }\end{array}$ & $\begin{array}{l}\text { Lower birth weight was associated with exposure in } \\
\text { the third trimester for PM10, the first and third } \\
\text { trimesters for } \mathrm{CO} \text {, the first trimester for } \mathrm{NO}_{2} \text { and } \mathrm{SO}_{2} \text {, } \\
\text { and the second and third trimesters for } \mathrm{PM}_{2} .5 \text {. Effect } \\
\text { estimates for PM2.5 were higher for infants of black } \\
\text { mothers than those of white mothers }\end{array}$ \\
\hline $\begin{array}{l}\text { Junger et al., } \\
2007[41]\end{array}$ & Rio de Janeiro, Brazil & All live births in 2002 & $\begin{array}{l}\text { To evaluate the effect of air pollution on low birth } \\
\text { weight in full term singleton newborns }\end{array}$ & $\begin{array}{l}\text { For } \mathrm{PM10}, \mathrm{CO} \text {, and } \mathrm{NO}_{2} \text {, no significant increases were } \\
\text { detected. For } \mathrm{SO}_{2} \text {, the OR of the fourth interquartile } \\
\text { range of exposure in the third trimester of pregnancy } \\
\text { was significant. For } \mathrm{O}_{3} \text {, the estimated OR was not } \\
\text { significant. When exposure variable was regarded as } \\
\text { a continuous measure, the OR for } \mathrm{PM10}, \mathrm{CO} \text {, and } \mathrm{SO}_{2} \\
\text { in the third trimester were not significant }\end{array}$ \\
\hline $\begin{array}{l}\text { Seo et al., } \\
2007[42]\end{array}$ & Seoul, Korea & $\begin{array}{l}\text { All singleton full-term } \\
\text { neonates (2002-2003) }\end{array}$ & $\begin{array}{l}\text { To determine the relationship between maternal } \\
\text { exposure to air pollution and low birth weight }\end{array}$ & $\begin{array}{l}\text { The risk of low birth weight significantly increased in } \\
\text { higher levels of } \mathrm{CO}, \mathrm{NO}_{2}, \mathrm{SO}_{2} \text {, and PM10 }\end{array}$ \\
\hline $\begin{array}{l}\text { Triche et al., } \\
2007 \text { [43] }\end{array}$ & Review & & $\begin{array}{l}\text { To assess diverse pregnancy outcome from } \\
\text { environmental factors }\end{array}$ & $\begin{array}{l}\text { Air pollution, cigarette smoking and pesticide } \\
\text { exposure were associated with low birth weight and } \\
\text { preterm delivery }\end{array}$ \\
\hline $\begin{array}{l}\text { Slama et al., } \\
2007 \text { [44] }\end{array}$ & Munich, Germany & $\begin{array}{l}\text { Women from a birth cohort } \\
\text { (LISA - Influences of Lifestyle } \\
\text { Related Factors on the } \\
\text { Human Immune System } \\
\text { and Development of Allergies } \\
\text { in Children) }\end{array}$ & $\begin{array}{l}\text { To characterize the influence of maternal exposure to } \\
\text { atmospheric pollutants due to road traffic and urban } \\
\text { activities on offspring term birth weight }\end{array}$ & $\begin{array}{l}\text { Increases in PM2.5 levels and PM2.5 absorbance were } \\
\text { associated with decreases in term birth weight }\end{array}$ \\
\hline $\begin{array}{l}\text { Hansen et al., } \\
2007[45]\end{array}$ & Brisbane, Australia & $\begin{array}{l}\text { Singleton full-term births } \\
(n=26,617)\end{array}$ & $\begin{array}{l}\text { To examine the relation of neonatal birth measures to } \\
\text { ambient pollution during pregnancy }\end{array}$ & $\begin{array}{l}\text { No strong evidence was documented suggesting an } \\
\text { association of ambient air pollution during pregnancy } \\
\text { and sub-optimal fetal growth }\end{array}$ \\
\hline $\begin{array}{l}\text { Dugandzic et al., } \\
2006 \text { [46] }\end{array}$ & $\begin{array}{l}\text { Ottawa, Ontario, } \\
\text { Canada }\end{array}$ & $\begin{array}{l}\text { Live singleton term births } \\
(n=74,284)(1988-2000)\end{array}$ & $\begin{array}{l}\text { To examine the association between low birth weight } \\
\text { among terminfants and ambient air pollution, by } \\
\text { trimester of exposure, in a region of lower level } \\
\text { exposures }\end{array}$ & $\begin{array}{l}\text { Exposure during the first trimester to relatively low } \\
\text { levels of } \mathrm{SO}_{2} \text { and } \mathrm{PM} 10 \text {. Some air pollutants may be } \\
\text { associated with a reduction in birth weight in term- } \\
\text { born infants }\end{array}$ \\
\hline
\end{tabular}


Table I. Summary of studies assessing the perinatal effects of criteria air pollutants - cont.

\begin{tabular}{|c|c|c|c|c|}
\hline (1) & (2) & (3) & (4) & (5) \\
\hline $\begin{array}{l}\text { Rogers et al., } \\
2006[47]\end{array}$ & Georgia, USA & $\begin{array}{l}\text { Case-control study of } \\
\text { mothers of pretermvery low } \\
\text { birth weight infants } \\
(n=128), \text { mothers of term, } \\
\text { appropriate-for-gestational- } \\
\text { age infants }(n=197) \\
(1986-1988)\end{array}$ & $\begin{array}{l}\text { To examine the association between maternal } \\
\text { exposure to particulate matter of }<10 \mu \mathrm{m} \text { and very } \\
\text { low birth weight }(<1500 \mathrm{~g}) \text { delivery }\end{array}$ & $\begin{array}{l}\text { Association between maternal exposure to air } \\
\text { pollution and low infant birth weight (particularly } \\
<1500 \mathrm{~g} \text { ) is at least partially attributable to an effect } \\
\text { on duration of gestation }\end{array}$ \\
\hline $\begin{array}{l}\text { Parker et al., } \\
2005[48]\end{array}$ & California, USA & $\begin{array}{l}\text { Singleton births delivered } \\
\text { at } 40 \text { weeks gestation (2000) }\end{array}$ & $\begin{array}{l}\text { To examine associations between birth weight and air } \\
\text { pollution among full-term infants in California }\end{array}$ & $\begin{array}{l}\text { An increased odds of low birth weight and a small } \\
\text { difference in mean birth weight between infants with } \\
\text { the highest and lowest exposures to PM } 2.5 \text { but not to } \\
\text { CO was found }\end{array}$ \\
\hline $\begin{array}{l}\text { Lee et al., } \\
2003[49]\end{array}$ & Seoul, Korea & Singleton neonates & $\begin{array}{l}\text { To determine which specific exposure times of specific } \\
\text { pollutants during pregnancy contribute to low birth } \\
\text { weight }\end{array}$ & $\begin{array}{l}\text { Exposure to } \mathrm{CO}, \mathrm{PM} 10, \mathrm{SO}_{2} \text { and } \mathrm{NO}_{2} \text { during early to } \\
\text { mid pregnancy contributes to risks for low birth weight }\end{array}$ \\
\hline $\begin{array}{l}\text { Maroziene et al., } \\
2002[50]\end{array}$ & Kaunas, Lithuania & $\begin{array}{l}\text { All singleton newborns } \\
(n=3,988)(1998)\end{array}$ & $\begin{array}{l}\text { To evaluate the relationship between ambient air } \\
\text { pollution and the occurrence of low birth weight and } \\
\text { preterm delivery }\end{array}$ & $\begin{array}{l}\text { A relationship between maternal exposure to ambient } \\
\text { formaldehyde and the risk of low birth weight, as well } \\
\text { as between } \mathrm{NO}_{2} \text { exposure and the risk of preterm } \\
\text { birth is suggested }\end{array}$ \\
\hline $\begin{array}{l}\text { Bobak et al., } \\
2000[51]\end{array}$ & Czech Republic & $\begin{array}{l}\text { All singleton live births } \\
\text { registered by the Czech } \\
\text { national birth register in } 1991 \\
\text { in } 67 \text { districts where at least } \\
\text { one pollutant was monitored } \\
(n=108,173)(1990-1991)\end{array}$ & $\begin{array}{l}\text { To test the hypothesis that air pollution may increase } \\
\text { the risk of adverse birth outcomes }\end{array}$ & $\begin{array}{l}\text { Intrauterine growth retardation was not associated } \\
\text { with any pollutant. The effects on low birth weight } \\
\text { and prematurity were marginally stronger for } \\
\text { exposures in the first trimester. Low gestational age } \\
\text { accounted for the association between } \mathrm{SO}_{2} \text { and low } \\
\text { birth weight }\end{array}$ \\
\hline $\begin{array}{l}\text { Wang et al., } \\
1997[52]\end{array}$ & Beijing, China & $\begin{array}{l}\text { Cohort of all pregnant } \\
\text { women, first-parity full-term } \\
\text { live births }(n=74,671) \\
(1988-1991)\end{array}$ & $\begin{array}{l}\text { To assess the relationship of maternal exposure to air } \\
\text { pollution during periods of pregnancy (entire and } \\
\text { specific periods) with birth weight }\end{array}$ & $\begin{array}{l}\text { Significant exposure-response relationship between } \\
\text { maternal exposure to } \mathrm{SO}_{2} \text { and total suspended } \\
\text { particles during the third trimester of pregnancy and } \\
\text { an excess risk of low birth weight was documented }\end{array}$ \\
\hline $\begin{array}{l}\text { Xu et al., } \\
1995[53]\end{array}$ & Beijing, China & $\begin{array}{l}\text { Cohort of all pregnant } \\
\text { women, resident women } \\
\text { who gave first live births } \\
\text { in } 1988(n=25,370)\end{array}$ & $\begin{array}{l}\text { To determine the acute effects of air pollution on } \\
\text { preterm delivery }\end{array}$ & $\begin{array}{l}\text { High levels of total suspended particulates and } \mathrm{SO}_{2} \\
\text { appear to contribute to excess risk of preterm delivery }\end{array}$ \\
\hline
\end{tabular}


Table II. Summary of studies assessing the effects of criteria air pollutants on infant mortality rate

\begin{tabular}{|c|c|c|c|c|}
\hline $\begin{array}{l}\text { Reference } \\
\text { (1) }\end{array}$ & $\begin{array}{l}\text { Location } \\
\text { (2) }\end{array}$ & $\begin{array}{l}\text { Population studied } \\
\text { (3) }\end{array}$ & $\begin{array}{l}\text { Aims } \\
(4)\end{array}$ & $\begin{array}{l}\text { Findings } \\
(5)\end{array}$ \\
\hline $\begin{array}{l}\text { Son et al., } \\
2008[54]\end{array}$ & Seoul, Korea & $\begin{array}{l}\text { Firstborn infants in Seoul, } \\
\text { Korea, during 1999-2003 }\end{array}$ & $\begin{array}{l}\text { To examine the relationship between air pollution and } \\
\text { post-neonatal mortality from all causes using both } \\
\text { case-crossover and time-series analyses }\end{array}$ & $\begin{array}{l}\text { The risk of post-neonatal infant death from all causes } \\
\text { was positively associated with all studied air } \\
\text { pollutants except ozone }\end{array}$ \\
\hline $\begin{array}{l}\text { Woodruff et al., } \\
2008[55]\end{array}$ & $\begin{array}{l}\text { U.S. counties with } \\
>250,000 \text { residents }\end{array}$ & $\begin{array}{l}\text { Infants born from } 1999 \text { to } \\
2002(n=\text { about } 3.5 \text { million } \\
\text { births, with } 6,639 \text { post- } \\
\text { neonatal infant deaths) }\end{array}$ & $\begin{array}{l}\text { To evaluate the relationship between cause-specific } \\
\text { post-neonatal infant mortality and chronic early-life } \\
\text { exposure to particulate matter and gaseous air } \\
\text { pollutants across the United States }\end{array}$ & $\begin{array}{l}\text { PM10 is a risk factor for respiratory-related post- } \\
\text { neonatal mortality and ozone may be associated with } \\
\text { sudden infant death syndrome }\end{array}$ \\
\hline $\begin{array}{l}\text { Heinrich et al., } \\
2007[56]\end{array}$ & Review & $\begin{array}{l}\text { Studies on the impact of fine } \\
\text { particle exposure on infant } \\
\text { death, lung function, } \\
\text { respiratory symptoms and } \\
\text { reproductive outcomes }\end{array}$ & $\begin{array}{l}\text { To review the children's susceptibility to ambient fine } \\
\text { particles and characteristics of infant and children } \\
\text { which underlie their increased susceptibility to PM }\end{array}$ & $\begin{array}{l}\text { Exposure to PM is strongly and consistently associated } \\
\text { with post-neonatal respiratory mortality and less } \\
\text { consistently with sudden infant death syndrome }\end{array}$ \\
\hline $\begin{array}{l}\text { Hajat et al., } \\
2007[57]\end{array}$ & $\begin{array}{l}10 \text { major cities } \\
\text { of England }\end{array}$ & $\begin{array}{l}\text { Daily time-series data of } \\
\text { air pollution and all infant } \\
\text { deaths between } 1990 \text { and } \\
2000\end{array}$ & $\begin{array}{l}\text { To investigate the effects of outdoor pollution } \\
\text { on infant mortality in the UK }\end{array}$ & $\begin{array}{l}\text { Few associations were observed between infant } \\
\text { deaths and most pollutants studied except for } \mathrm{SO}_{2}\end{array}$ \\
\hline $\begin{array}{l}\text { Rinne et al., } \\
2007 \text { [58] }\end{array}$ & Ecuador & $\begin{array}{l}\text { Eighty households in a rural } \\
\text { community }\end{array}$ & $\begin{array}{l}\text { To explore the relationship between biomass fuel, } \\
\text { infant mortality, and children's respiratory symptoms }\end{array}$ & $\begin{array}{l}\text { A significant trend for higher infant mortality among } \\
\text { households that cooked with a greater proportion of } \\
\text { biomass fuel was documented }\end{array}$ \\
\hline $\begin{array}{l}\text { Yang et al., } \\
2006[59]\end{array}$ & Taipei, Taiwan & $\begin{array}{l}\text { Infant ( } 27 \text { days }-1 \text { year }) \\
\text { mortality data }(1994-2000)\end{array}$ & $\begin{array}{l}\text { To examine the relationship between air pollution } \\
\text { exposure and post-neonatal infant mortality }\end{array}$ & $\begin{array}{l}\text { Air pollutants had a non-significant association with } \\
\text { the risk of post-neonatal deaths. This weak } \\
\text { association might be because of the subtropical } \\
\text { climate of the area under study }\end{array}$ \\
\hline
\end{tabular}


Table II. Summary of studies assessing the effects of criteria air pollutants on infant mortality rate - cont.

\begin{tabular}{|c|c|c|c|c|}
\hline (1) & (2) & (3) & (4) & (5) \\
\hline $\begin{array}{l}\text { Woodruff et al., } \\
2006[60]\end{array}$ & $\begin{array}{l}\text { California,USA } \\
(n=788 \text { infant } \\
\text { deaths })\end{array}$ & $\begin{array}{l}\text { Monitoring data for } \mathrm{PM} \leq 2.5 \\
\text { were linked to data of } \\
\text { infants born to mothers who } \\
\text { lived within } 5 \text { miles of } \\
\text { a monitor (1999-2000) }\end{array}$ & $\begin{array}{l}\text { To examine the relationship between long-term } \\
\text { exposure to fine PM air pollution and post-neonatal } \\
\text { infant mortality }\end{array}$ & $\begin{array}{l}\text { Increase in PM2.5 increased post-neonatal mortality } \\
\text { and sudden infant death syndrome }\end{array}$ \\
\hline $\begin{array}{l}\text { Romieu et al., } \\
2004 \text { [61] }\end{array}$ & $\begin{array}{l}\text { Ciudad Juarez, } \\
\text { Mexico }\end{array}$ & $\begin{array}{l}\text { Infant mortality and ambient } \\
\text { PM10 levels on days before } \\
\text { death (1997-2001) }\end{array}$ & $\begin{array}{l}\text { To study short-term PM10 exposure, relating to } \\
\text { increased respiratory-related infant mortality, and } \\
\text { estimated for poor living conditions }\end{array}$ & $\begin{array}{l}\text { Overall air pollutants did not affect infant mortality } \\
\text { but low socioeconomic condition increased this risk. } \\
\text { Increase in PM10 increased mortality }\end{array}$ \\
\hline $\begin{array}{l}\text { Glinianaia et al., } \\
2004 \text { [62] }\end{array}$ & Review & $\begin{array}{l}\text { Epidemiological studies } \\
\text { (15 studies included) }\end{array}$ & $\begin{array}{l}\text { Systematic review of an association between } \\
\text { particulate air pollution and infant mortality }\end{array}$ & $\begin{array}{l}\text { A strong association of particulate air pollution with } \\
\text { some causes of infant death was found }\end{array}$ \\
\hline $\begin{array}{l}\text { Lipfert et al., } \\
2000[63]\end{array}$ & USA & $\begin{array}{l}\text { U.S. birth and death records } \\
(1990)\end{array}$ & $\begin{array}{l}\text { To explore associations between infant mortality and } \\
\text { environmental factors, based on spatial relationships }\end{array}$ & $\begin{array}{l}\text { Significantnegative mortality associations were found } \\
\text { for SO4(2) without any role for outdoor PM2.5 }\end{array}$ \\
\hline $\begin{array}{l}\text { Bobak et al., } \\
1992[65]\end{array}$ & Czech Republic & $\begin{array}{l}\text { Infant mortality and air } \\
\text { pollution data in } 46 \text { of the } 85 \\
\text { districts (1986-1988) }\end{array}$ & $\begin{array}{l}\text { To assess the ecological associations of air pollution } \\
\text { and infant mortality }\end{array}$ & $\begin{array}{l}\text { The strongest effects were seen for the level of total } \\
\text { suspended particulates (TSP-10) followed by } \mathrm{SO}_{2} \text { level }\end{array}$ \\
\hline $\begin{array}{l}\text { Duchiade et al., } \\
1992 \text { [66] }\end{array}$ & Rio de Janeiro, Brazil & $\begin{array}{l}\text { Civil Register mortality data } \\
(1976-1986)\end{array}$ & $\begin{array}{l}\text { To study the associations between socioeconomic, } \\
\text { climatic, and air pollution variables and the levels } \\
\text { of mortality }\end{array}$ & $\begin{array}{l}\text { The mortality rates appeared to be associated with } \\
\text { the variations of the log of average pollution }\end{array}$ \\
\hline
\end{tabular}


Table III. Summary of studies assessing the effects of criteria air pollutants on childhood malignancies

\begin{tabular}{|c|c|c|c|c|}
\hline Reference & Location & Population studied & Aims & Findings \\
\hline $\begin{array}{l}\text { Weng et al., } \\
2009 \text { [67] }\end{array}$ & Taiwan & $\begin{array}{l}\text { A matched case-control study } \\
\text { using childhood deaths that } \\
\text { occurred in Taiwan from } 1996 \text { to } \\
2006\end{array}$ & $\begin{array}{l}\text { To investigate the relationship between traffic air } \\
\text { pollution exposure and development of leukaemia } \\
\text { in children aged }<14 \text { years }\end{array}$ & $\begin{array}{l}\text { A significant exposure-response relationship was found } \\
\text { between the petrol station density (per square kilometre) } \\
\text { (PSD) and the risk of childhood leukaemia }\end{array}$ \\
\hline $\begin{array}{l}\text { Whitworth et al., } \\
2008 \text { [68] }\end{array}$ & Texas, USA & $\begin{array}{l}\text { Cases of childhood } \\
\text { lymphohaematopoietic cancer } \\
(n=977)(1995-2004)\end{array}$ & $\begin{array}{l}\text { To assess whether census tracts with the highest } \\
\text { benzene or 1,3-butadiene ambient air levels have } \\
\text { increased childhood lymphohaematopoietic cancer } \\
\text { incidence }\end{array}$ & $\begin{array}{l}\text { High levels of benzene and 1,3-butadiene increased the risk } \\
\text { of all leukaemia, which was higher for acute myeloid } \\
\text { leukaemia (AML) than for acute lymphocytic leukaemia (ALL). } \\
\text { This association was not significant for lymphoma incidence }\end{array}$ \\
\hline $\begin{array}{l}\text { Weng et al., } \\
2008 \text { [69] }\end{array}$ & & $\begin{array}{l}\text { All eligible childhood leukaemia } \\
\text { deathsand controls (1995-2005) }\end{array}$ & $\begin{array}{l}\text { To investigate the relationship between petrochemical } \\
\text { air pollution and childhood leukaemia }\end{array}$ & $\begin{array}{l}\text { High levels of petrochemical air pollution significantly } \\
\text { increased the risk of developing childhood leukaemia }\end{array}$ \\
\hline $\begin{array}{l}\text { Millman et al., } \\
2008[70]\end{array}$ & $\begin{array}{l}\text { Review of studies } \\
\text { conducted in China }\end{array}$ & $\begin{array}{l}\text { Published environmental } \\
\text { studies, biomedical and } \\
\text { molecular/epidemiologic } \\
\text { research, and economic and } \\
\text { policy analyses in China }\end{array}$ & $\begin{array}{l}\text { To assess the effects of air pollution on children's } \\
\text { health and development }\end{array}$ & $\begin{array}{l}\text { One of the adverse effects of combustion-related air } \\
\text { pollution is the increased risk of cancer in children }\end{array}$ \\
\hline $\begin{array}{l}\text { Park et al., } \\
2008[33]\end{array}$ & $\begin{array}{l}\text { Review of studies } \\
\text { conducted in Asia }\end{array}$ & $\begin{array}{l}\text { Review of recently published } \\
\text { literature about cancer in Asia }\end{array}$ & $\begin{array}{l}\text { To identify important aetiological factors affecting } \\
\text { cancer risk in Asian populations }\end{array}$ & $\begin{array}{l}\text { Environmental exposure to indoor and outdoor air pollution, } \\
\text { arsenic, radon, asbestos and second hand smoke was shown } \\
\text { to increase cancer risk }\end{array}$ \\
\hline $\begin{array}{l}\text { Baker et al., } \\
2007[71]\end{array}$ & Meta-analysis & $\begin{array}{l}\text { Meta-analysis combined and } \\
\text { statistically analysed studies of } \\
\text { childhood leukaemia and nuclear } \\
\text { facilities }\end{array}$ & $\begin{array}{l}\text { To investigate whether living near nuclear facilities } \\
\text { increased the rate of childhood leukaemia }\end{array}$ & $\begin{array}{l}\text { The meta-analysis was able to show an increase in childhood } \\
\text { leukaemia near nuclear facilities, but does not support } \\
\text { a hypothesis to explain the excess }\end{array}$ \\
\hline $\begin{array}{l}\text { Reynolds et al., } \\
2004 \text { [72] }\end{array}$ & California, USA & $\begin{array}{l}\text { Cancers diagnosed in children } \\
\text { aged }<5 \text { years }(1988-1997) \\
(n=4369 \text { cases and } 8730 \\
\text { matched controls) }\end{array}$ & $\begin{array}{l}\text { To investigate whether traffic-related exposures can } \\
\text { increase the risk of childhood cancer }\end{array}$ & $\begin{array}{l}\text { No increased cancer risk was found among offspring } \\
\text { of mothers living in high traffic density areas for all cancer } \\
\text { sites or leukaemia }\end{array}$ \\
\hline $\begin{array}{l}\text { Raaschou-Nielsen } \\
\text { et al., } 2002 \text { [73] }\end{array}$ & Denmark & $\begin{array}{l}\text { Danish Cancer Registry data on } \\
\text { children ( } n=1,989 \text { cases of } \\
\text { leukaemia, tumour of the } \\
\text { central nervous system, or } \\
\text { malignant lymphoma, and 5,506 } \\
\text { controls; 1968-1991) }\end{array}$ & $\begin{array}{l}\text { To investigate the hypothesis that exposure } \\
\text { to traffic-related air pollution increases the risk } \\
\text { of cancer developing during childhood }\end{array}$ & $\begin{array}{l}\text { Traffic-related air pollution was not linked to the risk } \\
\text { of leukaemia or CNS tumour, but it was linked to the risk } \\
\text { of Hodgkin's disease }\end{array}$ \\
\hline
\end{tabular}


Table IV. Summary of studies assessing the effects of criteria air pollutants on oxidative stress and endothelial dysfunction among children and young adults

\begin{tabular}{|c|c|c|c|c|}
\hline Reference & Location & Population studied & Aims & Findings \\
\hline \multicolumn{5}{|l|}{ Oxidative stress } \\
\hline $\begin{array}{l}\text { Kelishadi et al., } \\
2009 \text { [29] }\end{array}$ & Isfahan, Iran & $\begin{array}{l}\text { A population-based sample } \\
\text { of children aged } 10-18 \text { years } \\
(n=374)\end{array}$ & $\begin{array}{l}\text { To determine the association of air pollution as well as } \\
\text { dietary and physical activity habits with markers of } \\
\text { inflammation, oxidative stress and insulin resistance }\end{array}$ & $\begin{array}{l}\text { The Pollutant Standard Index (PSI) and the level } \\
\text { of fine particulate matter had a significant independent } \\
\text { association with all biomarkers studied }\end{array}$ \\
\hline $\begin{array}{l}\text { Yang, Omaye, } \\
2009[74]\end{array}$ & Review & $\begin{array}{l}\text { Review of studies on air } \\
\text { pollution and chronic } \\
\text { obstructive pulmonary } \\
\text { diseases, cardiovascular } \\
\text { diseases, asthma, and cancer }\end{array}$ & $\begin{array}{l}\text { To provide some insight into the health problems } \\
\text { associated with various air pollutants and their } \\
\text { relationship in promoting chronic diseases through } \\
\text { changes in oxidative stress and modulation of gene } \\
\text { expression }\end{array}$ & $\begin{array}{l}\text { By-products of oxidative stress found in air pollutants } \\
\text { are common initiators or promoters of the damage } \\
\text { produced in chronic diseases }\end{array}$ \\
\hline $\begin{array}{l}\text { Chuang et al., } \\
2007[75]\end{array}$ & Taipei, Taiwan & $\begin{array}{l}\text { Young healthy university } \\
\text { students }(n=76)\end{array}$ & $\begin{array}{l}\text { To investigate whether biological mechanisms linking } \\
\text { air pollution to cardiovascular events occurred } \\
\text { concurrently in human subjects exposed to urban air } \\
\text { pollutants }\end{array}$ & $\begin{array}{l}\text { Air pollution is associated with inflammation, } \\
\text { oxidative stress and blood coagulation in healthy } \\
\text { young humans }\end{array}$ \\
\hline \multicolumn{5}{|c|}{ Endothelial dysfunction } \\
\hline Brook, 2008 [76] & Review & $\begin{array}{l}\text { Review of studies on air } \\
\text { pollution and cardiovascular } \\
\text { diseases }\end{array}$ & $\begin{array}{l}\text { To address the cardiovascular effects of air pollution } \\
\text { and related mechanisms }\end{array}$ & $\begin{array}{l}\text { Air particle exposure may both trigger acute events as } \\
\text { well as prompt the chronic development of } \\
\text { cardiovascular diseases. One of the mechanisms is by } \\
\text { triggering acute endothelial dysfunction }\end{array}$ \\
\hline $\begin{array}{l}\text { Nadadur et al., } \\
2008 \text { [77] }\end{array}$ & USA & $\begin{array}{l}\text { Differential gene expression } \\
\text { and transcription factor } \\
\text { activation profiles in human } \\
\text { vascular endothelial cells } \\
\text { exposed to a non-cytotoxic } \\
\text { dose of fly ash or } V \text { following } \\
\text { semi-global gene expression } \\
\text { profiling of approximately } \\
8000 \text { genes }\end{array}$ & $\begin{array}{l}\text { To explore potential biomarkers for PM-induced } \\
\text { endothelial dysfunction }\end{array}$ & $\begin{array}{l}\text { Cardiovascular effects associated with exposure to PM } \\
\text { may be mediated by perturbations in endothelial cell } \\
\text { permeability, membrane integrity, and ultimately } \\
\text { endothelial dysfunction }\end{array}$ \\
\hline
\end{tabular}




\begin{tabular}{|c|c|c|c|c|}
\hline 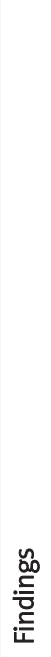 & 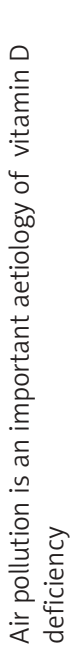 & 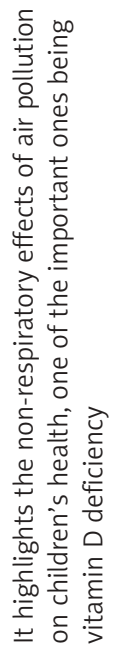 & 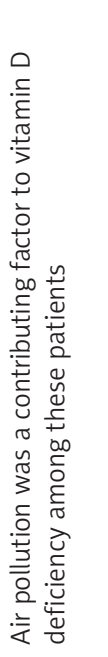 & 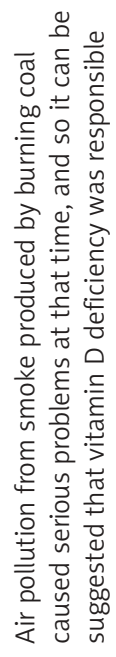 \\
\hline$\frac{n}{\frac{E}{\alpha}}$ & 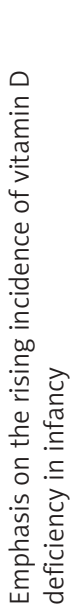 & 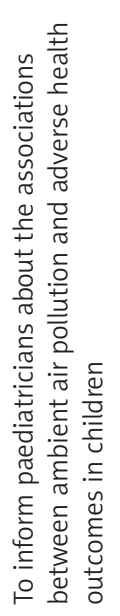 & 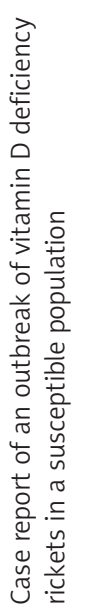 & 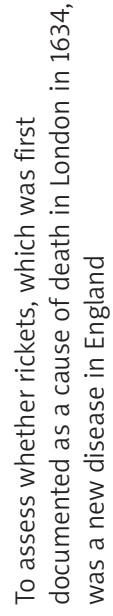 \\
\hline 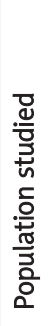 & 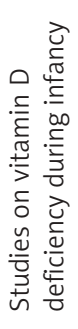 & 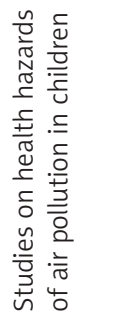 & 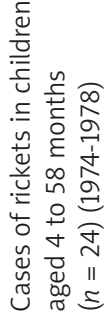 & 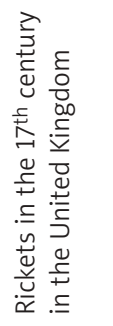 \\
\hline كَّ & 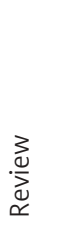 & . & 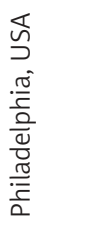 & 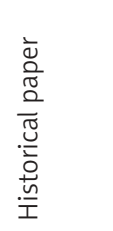 \\
\hline 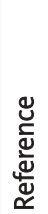 & 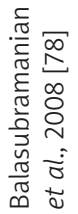 & 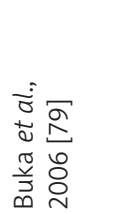 & 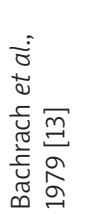 & 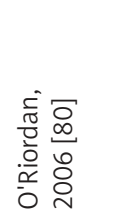 \\
\hline
\end{tabular}

particularly important for children, who are susceptible to short-term and long-term effects of air pollutants.

Facilities should be provided for families to become aware of the quality of the air year round and to check daily air-quality levels and air-pollution forecasts by mass media, local weather reports and other available public information sources. This is especially important for smog levels during hot weather. Protective measures should be taken into account for children and pregnant women to reduce their exposure to air pollutants, e.g. children and pregnant women should avoid congested streets and rush hour traffic, and families should try to limit the amount of time their child spends outdoors in vigorous activity if the air quality is unhealthy.

\section{Conclusions}

Air pollution is a global health issue with serious public health implications, particularly for children. Usually respiratory effects of air pollutants are considered, but the importance of other health hazards should also be highlighted. In addition to short-term effects, exposure to criteria air pollutants from early life might have long-term risks principally for chronic non-communicable diseases such as cardiovascular diseases and cancers. In view of the emerging epidemic of chronic disease in low- and middle-income countries, the vicious cycle of rapid urbanization in such communities resulting in increasing levels of air pollution and its consequent effects on chronic diseases, as well as the limited financial resources of these countries for planning effective air pollution control programmes, public health and regulatory policies for air quality protection should be integrated into the main priorities of the primary health care system and into the educational curriculum of health professionals.

\section{References}

1. Samet J, Krewski D. Health effects associated with exposure to ambient air pollution. J Toxicol Environ Health A 2007; 70: 227-42.

2. Chen $\mathrm{B}$, Kan $\mathrm{H}$. Air pollution and population health: a global challenge. Environ Health Prev Med 2008; 13: 94-101.

3. Brook RD, Franklin B, Cascio W, et al.; Expert Panel on Population and Prevention Science of the American Heart Association. Air pollution and cardiovascular disease: a statement for healthcare professionals from the Expert Panel on Population and Prevention Science of the American Heart Association. Circulation 2004; 109: 2655-71.

4. Han X, Naeher LP. A review of traffic-related air pollution exposure assessment studies in the developing world. Environ Int 2006; 32: 106-20.

5. Kim JJ; American Academy of Pediatrics Committee on Environmental Health. Ambient air pollution: health hazards to children. Pediatrics 2004; 114: 1699-707.

6. Brunekreef B. Health effects of air pollution observed in cohort studies in Europe. J Expo Sci Environ Epidemiol 2007; 17 (Suppl 2): S61-5. 
7. Yusuf S, Vaz M, Pais P. Tackling the challenge of cardiovascular disease burden in developing countries. Am Heart J 2004; 148: 1-4.

8. Kelishadi R, Ardalan G, Gheiratmand R, Adeli K, Delavari A, Majdzadeh R; Caspian Study Group. Paediatric metabolic syndrome and associated anthropometric indices: the CASPIAN Study. Acta Paediatr 2006; 95: 1625-34.

9. Kelishadi R, Ardalan G, Gheiratmand R, et al.; CASPIAN Study Group. Association of physical activity and dietary behaviours in relation to the body mass index in a national sample of Iranian children and adolescents: CASPIAN Study. Bull World Health Organ 2007; 85: 19-26.

10. Kelishadi R. Childhood overweight, obesity, and the metabolic syndrome in developing countries. Epidemiol Rev 2007; 29: 62-76.

11. Kelishadi R, Cook SR, Motlagh ME, et al. Metabolically obese normal weight and phenotypically obese metabolically normal youths: the CASPIAN Study. J Am Diet Assoc 2008; 108: 82-90.

12. Kelishadi R, Ardalan G, Gheiratmand R, et al.; CASPIAN Study Group. Blood pressure and its influencing factors in a national representative sample of Iranian children and adolescents: the CASPIAN Study. Eur J Cardiovasc Prev Rehabil 2006; 13: 956-63.

13. Bachrach S, Fisher J, Parks JS. An outbreak of vitamin D deficiency rickets in a susceptible population. Pediatrics 1979; 64: 871-7.

14. Kelishadi R, Razaghi EM, Gouya MM, et al.; CASPIAN Study Group. Association of physical activity and the metabolic syndrome in children and adolescents: CASPIAN Study. Horm Res 2007; 67: 46-52.

15. Kelishadi R, Gouya MM, Adeli K, et al.; CASPIAN Study Group. Factors associated with the metabolic syndrome in a national sample of youths: CASPIAN Study. Nutr Metab Cardiovasc Dis 2008; 18: 461-70.

16. Sinclair KD, Lea RG, Rees WD, Young LE. The developmental origins of health and disease: current theories and epigenetic mechanisms. Soc Reprod Fertil Suppl 2007; 64: 425-43.

17. Evensen KA, Steinshamn S, Tjønna AE, et al. Effects of preterm birth and fetal growth retardation on cardiovascular risk factors in young adulthood. Early Hum Dev 2008; 85: 239-45.

18. Delisle HF. Poverty: the double burden of malnutrition in mothers and the intergenerational impact. Ann N Y Acad Sci 2008; 1136: 172-84.

19. Victora CG, Adair L, Fall C, et al. Maternal and Child Undernutrition Study Group. Maternal and child undernutrition: consequences for adult health and human capital. Lancet 2008; 371: 340-57.

20. Power C, Atherton K, Strachan DP, et al. Life-course influences on health in British adults: effects of socioeconomic position in childhood and adulthood. Int J Epidemiol 2007; 36: 532-9.

21. Strand BH, Kunst A. Childhood socioeconomic position and cause-specific mortality in early adulthood. Am J Epidemiol 2007; 165: 85-93.

22. Beyond Economic Growth, http.//www.worldbank.org/ depweb/beyond/beyond.htm (accessed 5 April, 2009).

23. Yusuf S, Reddy S, Ounpuu S, Anand S. Global burden of cardiovascular diseases. Part I: general considerations, the epidemiologic transition, risk factors, and impact of urbanization. Circulation 2001; 104: 2746-53.

24. Miranda JJ, Kinra S, Casas JP, Davey Smith G, Ebrahim S. Non-communicable diseases in low- and middle-income countries: context, determinants and health policy. Trop Med Int Health 2008; 13: 1225-34
25. Holgate ST, Devlin RB, Wilson SJ, Frew AJ. Health effects of acute exposure to air pollution. Part II: Healthy subjects exposed to concentrated ambient particles. Res Rep Health Eff Inst 2003; 112: 31-50.

26. Huang SL, Hsu MK, Chan CC. Effects of submicrometer particle compositions on cytokine production and lipid peroxidation of human bronchial epithelial cells. Environ Health Perspect 2003; 111: 478-82.

27. Rückerl R, Ibald-Mulli A, Koenig W. Air pollution and markers of inflammation and coagulation in patients with coronary heart disease. Am J Respir Crit Care Med 2006; 173: 432-41.

28. Chuang KJ, Chan CC, Su TC, Lee CT, Tang CS. The effect of urban air pollution on inflammation, oxidative stress, coagulation, and autonomic dysfunction in young adults. Am J Respir Crit Care Med 2007; 176: 370-6.

29. Kelishadi R, Mirghaffari N, Poursafa P, Gidding SS. Lifestyle and environmental factors associated with inflammation, oxidative stress and insulin resistance in children. Atherosclerosis 2009; 203: 311-9.

30. Dominguez LJ, Galioto A, Ferlisi A, et al. Ageing, lifestyle modifications, and cardiovascular disease in developing countries. J Nutr Health Aging 2006; 10: 143-9.

31. Hjartåker A, Langseth $H$, Weiderpass E. Obesity and diabetes epidemics: cancer repercussions. Adv Exp Med Biol 2008; 630: 72-93.

32. Nejjari C, Filleul L, Zidouni N, et al. Air pollution: a new respiratory risk for cities in low-income countries. Int J Tuberc Lung Dis 2003; 7: 223-31.

33. Park S, Bae J, Nam BH, Yoo KY. Aetiology of cancer in Asia. Asian Pac J Cancer Prev 2008; 9: 371-80.

34. Zeka A, Melly SJ, Schwartz J. The effects of socioeconomic status and indices of physical environment on reduced birth weight and preterm births in Eastern Massachusetts. Environ Health 2008; 7: 60.

35. Suh YJ, KimH, Seo JH, et al. Different effects of PM(10) exposure on preterm birth by gestational period estimated from time-dependent survival analyses. Int Arch Occup Environ Health 2008; 82: 613-21.

36. Parker JD, Mendola P, Woodruff TJ. Preterm birth after the Utah Valley Steel Mill closure: a natural experiment. Epidemiology 2008; 19: 820-3.

37. Stillerman KP, Mattison DR, Giudice LC, Woodruff TJ. Environmental exposures and adverse pregnancy outcomes: a review of the science. Reprod Sci 2008; 15: 631-50.

38. Choi H, Rauh V, Garfinkel R, Tu Y, Perera FP. Prenatal exposure to airborne polycyclic aromatic hydrocarbons and risk of intrauterine growth restriction. Environ Health Perspect 2008; 116: 658-65.

39. Brauer M, Lencar C, Tamburic L, Koehoorn M, Demers P, Karr C. A cohort study of traffic-related air pollution impacts on birth outcomes. Environ Health Perspect 2008; 116: 680-6.

40. Bell ML, Ebisu K, Belanger K. Ambient air pollution and low birth weight in Connecticut and Massachusetts. Environ Health Perspect 2007; 115: 1118-24.

41. Junger WL, Leon AP. Air pollution and low birth weight in the city of Rio de Janeiro, Brazil, 2002 [Brazilian]. Cad Saude Publica 2007; 23 (Suppl 4): S588-98.

42. Seo JH, Ha EH, Kim OJ, et al. [Environmental health surveillance of low birth weight in Seoul using air monitoring and birth data. J Prev Med Public Health 2007; 40: 363-70.

43. Triche EW, Hossain N. Environmental factors implicated in the causation of adverse pregnancy outcome. Semin Perinatol 2007; 31: 240-2. 
44. Slama R, Morgenstern V, Cyrys J, et al.; LISA Study Group. Traffic-related atmospheric pollutants levels during pregnancy and offspring's term birth weight: a study relying on a land-use regression exposure model. Environ Health Perspect 2007; 115: 1283-92.

45. Hansen C, Neller A, Williams G, Simpson R. Low levels of ambient air pollution during pregnancy and fetal growth among term neonates in Brisbane, Australia. Environ Res 2007; 103: 383-9.

46. Dugandzic R, Dodds L, Stieb D, Smith-Doiron M. The association between low level exposures to ambient air pollution and term low birth weight: a retrospective cohort study. Environ Health 2006; 5: 3.

47. Rogers JF, Dunlop AL. Air pollution and very low birth weight infants: a target population? Pediatrics 2006; 118: 156-64.

48. Parker JD, Woodruff TJ, Basu R, Schoendorf KC. Air pollution and birth weight among term infants in California. Pediatrics 2005; 115: 121-8.

49. Lee BE, Ha EH, Park HS, et al. Exposure to air pollution during different gestational phases contributes to risks of low birth weight. Hum Reprod 2003; 18: 638-43.

50. Maroziene L, Grazuleviciene R. Maternal exposure to lowlevel air pollution and pregnancy outcomes: a populationbased study. Environ Health 2002; 1: 6.

51. Bobak M. Outdoor air pollution, low birth weight, and prematurity. Environ Health Perspect 2000; 108: 173-6.

52. Wang X, Ding H, Ryan L, Xu X. Association between air pollution and low birth weight: a community-based study. Environ Health Perspect 1997; 105: 514-20.

53. Xu X, Ding H, Wang X. Acute effects of total suspended particles and sulfur dioxides on preterm delivery: a community-based cohort study. Arch Environ Health 1995; 50: 407-15.

54. Son JY, Cho YS, Lee JT. Effects of air pollution on postneonatal infant mortality among firstborn infants in Seoul, Korea: case-crossover and time-series analyses. Arch Environ Occup Health 2008; 63: 108-13.

55. Woodruff TJ, Darrow LA, Parker JD. Air pollution and post neonatal infant mortality in the United States, 1999-2002. Environ Health Perspect 2008; 116: 110-5.

56. Heinrich J, Slama R. Fine particles, a major threat to children. Int J Hyg Environ Health 2007; 210: 617-22.

57. Hajat S, Armstrong B, Wilkinson P, Busby A, Dolk H. Outdoor air pollution and infant mortality: analysis of daily time-series data in 10 English cities. J Epidemiol Community Health 2007; 61: 719-22.

58. Rinne ST, Rodas EJ, Rinne ML, Simpson JM, Glickman LT. Use of biomass fuel is associated with infant mortality and child health in trend analysis. Am J Trop Med Hyg 2007; 76: 585-91.

59. Yang CY, Hsieh HJ, Tsai SS, Wu TN, Chiu HF. Correlation between air pollution and postneonatal mortality in a subtropical city: Taipei, Taiwan. J Toxicol Environ Health A 2006; 69: 2033-40.

60. Woodruff TJ, Parker JD, Schoendorf KC. Fine particulate matter (PM2.5) air pollution and selected causes of postneonatal infant mortality in California. Environ Health Perspect 2006; 114: 786-90.

61. Romieu I, Ramírez-Aguilar M, Moreno-Macias H, et al. Infant mortality and air pollution: modifying effect by social class. J Occup Environ Med 2004; 46: 1210-6.

62. Glinianaia SV, Rankin J, Bell R, Pless-Mulloli T, Howel D. Does particulate air pollution contribute to infant death? A systematic review. Environ Health Perspect 2004; 112: 1365-71.
63. Lipfert FW, Zhang J, Wyzga RE. Infant mortality and air pollution: a comprehensive analysis of U.S. data for 1990. J Air Waste Manag Assoc 2000; 50: 1350-66.

64. Loomis D, Castillejos M, Gold DR, McDonnell W, BorjaAburtoVH. Air pollution and infant mortality in Mexico City. Epidemiology 1999; 10: 118-23.

65. Bobak M, Leon DA. Air pollution and infant mortality in the Czech Republic, 1986-88. Lancet 1992; 340: 1010-4.

66. Duchiade MP, Beltrao KI. Infant mortality by cause of death in the Rio de Janeiro metropolitan area, 1976-1986: association with socioeconomic, climatic and air pollution variables. Rev Bras Estud Popul 1992; 9: 115-37.

67. Weng HH, Tsai SS, Chiu HF, Wu TN, Yang CY. Childhood leukemia and traffic air pollution in Taiwan: petrol station density as an indicator. J Toxicol Environ Health A 2009; 72: 83-7.

68. Whitworth KW, Symanski E, Coker AL. Childhood lymphohematopoietic cancer incidence and hazardous air pollutants in southeast Texas, 1995-2004. Environ Health Perspect 2008; 116: 1576-80.

69. Weng HH, Tsai SS, Chiu HF, Wu TN, Yang CY. Association of childhood leukemia with residential exposure to petrochemical air pollution in Taiwan. Inhal Toxicol 2008; 20: 31-6.

70. Millman A, Tang D, Perera FP. Air pollution threatens the health of children in China. Pediatrics 2008; 122: 620-8.

71. Baker PJ, Hoel DG. Meta-analysis of standardized incidence and mortality rates of childhood leukaemia in proximity to nuclear facilities. Eur J Cancer Care (Engl) 2007; 16: 355-63.

72. Reynolds P, Von Behren J, Gunier RB, Goldberg DE, Hertz A. Residential exposure to traffic in California and childhood cancer. Epidemiology 2004; 15: 6-12.

73. Raaschou-Nielsen O, Hertel O, Thomsen BL, Olsen JH. Traffic-related air pollution at the place of residence and risk of cancer among children. Ugeskr Laeger 2002; 164: 2283-7.

74. Yang W, Omaye ST. Air pollutants, oxidative stress and human health. Mutat Res 2009; 674: 45-54.

75. Chuang KJ, Chan CC, Su TC, Lee CT, Tang CS. The effect of urban air pollution on inflammation, oxidative stress, coagulation, and autonomic dysfunction in young adults. Am J Respir Crit Care Med 2007; 176: 370-6.

76. Brook RD. Cardiovascular effects of air pollution. Clin Sci (Lond) 2008; 115: 175-87.

77. Nadadur SS, Haykal-Coates N, Mudipalli A, Costa DL. Endothelial effects of emission source particles: acute toxic response gene expression profiles. Toxicol In Vitro 2008; 23: 67-77.

78. Balasubramanian S, Ganesh R. Vitamin D deficiency in exclusively breast-fed infants. Indian J Med Res 2008; 127: 250-5.

79. Buka I, Koranteng S, Osornio-Vargas AR. The effects of air pollution on the health of children. Paediatr Child Health 2006; 11: 513-6.

80. O'Riordan JL. Rickets in the 17th century. J Bone Miner Res 2006; 21: 1506-10. 